\title{
Dobbeltdiagnosepatienters møde med det psykiatriske behandlingssystem
}

Katrine Schepelern Johansen, Sidsel Busch, Pernille Pinderup Jeppesen, Solvej Mårtensson, Heidi Poulsen \& Jonathan Led Larsen

Kompetencecenter for Dobbeltdiagnoser, Region Hovedstadens Psykiatri Katrine.schepelern.johansen@regionh.dk

Johansen, Katrine Schepelern; Busch, Sidsel; Jeppesen, Pernille Pinderup; Mårtensson, Solvej; Poulsen, Heidi; Larsen, Jonathan Led (2018). ‘Dobbeltdiagnosepatienters møde med det psykiatriske behandlingssystem' i Tidsskrift for Forskning i Sygdom og Samfund, nr. 28, 155-172

I denne artikel præsenterer vi en interviewundersøgelse med 17 dobbeltdiagnosepatienter (patienter der både har et misbrug og en anden psykiatrisk lidelse), der beskriver deres erfaringer med at blive afvist eller behandlet dårligt $i$ mødet med det psykiatriske behandlingssystem. På baggrund af en indholdsanalyse af patienternes fortællinger har vi identificeret tre forskellige svar på, hvorfor patienterne bliver mødt på denne måde. For det første fordi stofmisbrug generelt $i$ samfundet bliver omfattet af stigmatisering, og at det også galder personalet på de psykiatriske afdelinger. For det andet fordi patienterne ikke lever op til rollen som rigtige patienter - bl.a. fordi de fortsætter med at misbruge, når de kommer i psykiatrisk behandling. Og for det tredje fordi psykiatrien arbejder med en forstålse af psykisk sygdom - som værende præcist afgrænsede sygdomsenheder - der vanskeliggør behandlingen af komplekse lidelser som dobbeltdiagnose. Som afsluttende perspektivering peger vi på de ønsker, som patienterne selv har til det psykiatriske behandlingssystem, 
nemlig at blive mødt som hele mennesker og at få behandlet deres problemer - inklusivt misbrug - professionelt af personalet.

Patients with a dual diagnosis and their encounter with the psychiatric treatment system

In this article, we present 17 interviews with patients with a dual diagnosis (the coexistence of a substance use disorder and a psychiatric disorder). These patients uniformly describe experiences of being rejected or treated as second rank patients by the psychiatric treatment system. Based on a content-analysis of the 17 interviews we identify three different answers to the question of why patients are being meet this way. Firstly, drug use is generally stigmatized by society at large - and hence also by psychiatric staff. Secondly, patients with a dual diagnosis is living up to the traditional role of patient, among other things because they continue to use. And thirdly, the concept of disease that psychiatry apply - that of sharply distinguished disease entities - complicates treatment of complex diseases, such as dual diagnosis. We end the article by presenting the wished of the patients with regard to the psychiatric treatment system: to be met as a person and to receive competent treatment for their problems, including the substance use.

\section{Indledning}

Mennesker, der både har en psykisk sygdom og et misbrug ${ }^{1}$ af stoffer $^{2}$, kaldes i psykiatrien for patienter med en dobbeltdiagnose. Selvom misbrug af stoffer (og andre rusmidler) formelt set er en psykiatrisk diagnose, så opleves psykiatriske patienter med et misbrug som en problematisk patientgruppe i psykiatrien. Således har den psykiatriske overlæge, Lars Merinder, beskrevet denne patientgruppe som 'psykiatriens stedbørn' (Merinder, 2007). Han peger på følgende problemer: Kendskab til misbrug i psykiatrien er mangelfuldt, der er et manglende samarbejde mellem psykiatri og misbrugsbehandling, og der mangler en politisk og organisatorisk indsats for at få etableret effektive tilbud.

Igennem de seneste år har der været igangsat en række forskellige projekter, der har sigtet på at forbedre indsatsen i psykiatrien - blandet andet via satspuljen, hvor der fra 2012-2015 puljen blev kørt en række projekter i psykiatrien under overskriften 'En styrket indsats for Dobbeltdiagnosticerede', der pegede netop på behovet for at styrke indsatsen. Andre projekter har handlet om at understøtte 
samarbejdet mellem den kommunale misbrugsbehandling og den regionale behandlingspsykiatri - for eksempel satspuljeprojektet 'Integreret Indsats'.

Det er en stor gruppe af patienter i psykiatrien, der også har et misbrug, og som dermed er i risiko for ikke at få en god behandling. En dansk registerundersøgelse af misbrug blandt patienter i psykiatrien finder en livstidsprævalens for misbrug af alkohol og stoffer på ca. $30 \%$, hvor langt de fleste har et misbrug af alkohol (Toftdahl, Nordentoft \& Hjorthoj, 2016). Dette tal er et minimumstal, da vi ved, at der er en underdiagnosticering af misbrug hos psykiatriske patienter (Hansen et al., 2000). Derudover er der tale om patienter, der er vanskeligere at behandle, fordi de to lidelser gensidigt forstærker hinanden, og som typisk har dårligere forløb og sværere symptomer (Schmidt, Hesse \& Lykke, 2011).

I denne artikel vil vi undersøge, hvordan denne 'stedmoderlige' behandling (Merinder, 2007) af patienter med en dobbeltdiagnose opleves af patienterne selv og give nogle forklaringer på, hvorfor den foregår. Vi vil præsentere resultaterne fra en kvalitativ interviewundersøgelse med 17 patienter med en dobbeltdiagnose, der blandet andet omhandler disse patienters erfaringer med psykiatrien. I interviewene identificerer vi tre overordnede, men forbundne, temaer: 1) Misbrug mødes med fordømmelse i psykiatrien, 2) Patienter med en dobbeltdiagnose er andenrangs patienter, og 3) Patienterne oplever ikke at få hjælp til deres problemer - herunder misbrug. Vi vil - med hjælp fra litteratur om stigmatisering, patientrolle, sociale teknologier og kritik af de psykiatriske diagnosesystemer og yderligere eksempler fra psykiatrien - udfolde disse tre punkter for herigennem at forklare, hvorfor de findes. Og dermed også identificere, hvilke udfordringer man står med, hvis man ønsker at ændre psykiatriens syn på stoffer og ikke mindst de patienter, der bruger dem.

Efter denne indledning følger to afsnit, hvor vi dels præsenterer metode, dels det felt som vi arbejder med. Herefter kommer de tre analytiske afsnit, hvor de tre temaer præsenteres og analyseres. Afslutningsvis præsenterer vi dobbeltdiagnosepatienternes egne ønsker til, hvordan de gerne vil mødes i psykiatrien.

\section{Metode}

De 17 patienter er blevet interviewet i forbindelse med en undersøgelse af sammenhængen mellem dobbeltdiagnose og bæltefiksering (Busch, Rasmussen, Mårtensson \& Johansen, 2017). I disse interview blev patienterne også bedt om at fortælle om deres generelle erfaringer med at være patient med en dobbeltdiag- 
nose i psykiatrien, og om hvordan de godt kunne tænke sig at blive mødt af det psykiatriske behandlingssystem. Det er disse dele af interviewene, der danner det empiriske udgangspunkt for artiklen.

At patienterne er blevet rekrutteret i forbindelse med en undersøgelse om bæltefiksering, og at hovedparten af patienterne selv havde tidligere erfaringer med bæltefiksering betyder, at vi har talt med patienter, der har haft nogle problematiske forløb i psykiatrien, og det kan selvfølgelig betyde, at patienterne tegner et mere negativt billede, end hvis vi havde talt med et andet udsnit af patienter med en dobbeltdiagnose. Vi vurderer dog, at fundene i undersøgelsen også er dækkende for dobbeltdiagnosepatienter mere generelt. Dette baserer vi på flere forhold. Dels er der en fin overensstemmelse mellem de historier, som vores patienter fortæller, og andre undersøgelser af dobbeltdiagnosepatienters syn på behandlingen (Johansen, 2009; Landheim et al., 2016; Schulte, Meier \& Stirling, 2011). Dels modsvares patienternes fortællinger af psykiatrisk personales udsagn om ikke at være klædt godt nok på til at håndtere patienter med en dobbeltdiagnose, at de mangler viden og redskaber, og historier om, at en del psykiatrisk personale fortsat ikke mener, at misbrug er en behandlingsopgave for psykiatrien (Busch, Rasmussen, Mårtensson \& Johansen, 2017; Ludvigsen \& Brünés, 2013; Pinderup, Forthcomming).

De fleste af patienterne blev rekrutteret på afdeling M på Psykiatrisk Center Sct. Hans, der er en specialafdeling for dobbeltdiagnosepatienter i Region Hovedstadens Psykiatri. Afdelingssygeplejerskerne spurgte på vores vegne relevante patienter (dvs. patienter, der havde oplevet at blive bæltefikseret under tidligere indlæggelser), om de ville deltage i interviewundersøgelsen. Størstedelen af de adspurgte patienter indvilligede $i$ at deltage. Derudover er tre patienter blevet rekrutteret fra en retspsykiatrisk afdeling, en patient fra et botilbud og en patient fra et opsøgende specialteam. Rekrutteringen af disse patienter er foregået ved, at patienternes kontaktperson i den pågældende institution, på vores vegne, har spurgt patienterne, om de vil deltage i interviewundersøgelsen.

Der er i alt interviewet 17 patienter, heraf fem kvinder og 12 mænd. 14 patienter havde erfaringer med bæltefikseringer. Størstedelen af patienterne har erfaringer med såvel akutmodtagelser som åbne og lukkende afsnit, og de fleste har talrige korte og flere langvarige indlæggelser bag sig. Alle patienterne kommer fra Region Hovedstaden.

Der blev udarbejdet en interviewguide forud for interviewene. I praksis udfoldede de fleste interview sig dog som en form for samtaleinterview, hvor guidens temaer blev brugt som rettesnor for samtalerne. I interviewene bad vi indled- 
ningsvis patienterne fortælle, hvad de fejler, hvilke rusmidler de bruger og hvilke typer afdelinger, de har været indlagt på (akutmodtagelser, åbne og lukkede afsnit). Vi bad patienterne fortælle om, hvordan det er at være patient i psykiatrien, når man også har et misbrug og om deres egne erfaringer med bæltefikseringer. Vi spurgte også til, hvad de tænker, der skal til for at forebygge brugen af tvang og bæltefikseringer i forhold til patienter med en dobbeltdiagnose. Endelig talte vi også med dem om, hvordan de gerne ville mødes i deres kontakt med psykiatrien.

De fleste af de patienter, der blev interviewet, havde meget at fortælle og var ivrige efter at dele deres erfaringer og meninger. Det længste interview varede 2 $1 / 2$ time, det korteste tog 10 minutter, og størstedelen varede en god times tid. Hvor det har været muligt, er interviewene blevet optaget, og interviewer har samtidig skrevet noter undervejs. Hvor interviewene ikke er blevet optaget - fordi patienterne ikke ønskede det - har interviewer skrevet grundige noter undervejs.

Interviewene er gennemført af en af artiklens forfattere (SB), der har stor erfaring med at interviewe mennesker, der lever med psykisk sygdom for at sikre, at interviewene ikke skulle blive ubehagelige for patienterne. Der er anvendt informeret samtykke til patienterne. I den proces har vi været meget tydelige omkring, hvad formålet med interviewet var, samt oplyst patienterne om, at de når som helst og uden begrundelse kan trække deres bidrag tilbage, hvis de fortryder deltagelse. Alle er blevet lovet anonymitet. Dernæst har vi sikret os, at patienterne har ønsket at deltage. Undersøgelsen er anmeldt til Datatilsynet.

Analysen af data er foregået som en induktiv proces. Interviewene er blevet gennemlyttet og noter gennemlæst og undervejs er de centrale temaer i patienternes fortællinger blevet identificeret. Disse temaer har vi så analyseret ud fra en række begreber og temaer hentet dels fra litteraturen omkring dobbeltdiagnose og dels mere generelt fra den kritiske antropologi og sociologi. Efter etableringen af de analytiske begreber har vi været tilbage til empirien og bekræftet begrebernes relevans i forhold til at forstå det empiriske materiale. Analysen har sigtet på at etablere nogle forklaringer på, hvordan de afvisende praksisser, som patienterne fortæller eksisterer, meningsfyldt kan eksistere i et behandlingssystem, som formelt set bør behandle denne gruppe af patienter.

Udover interviewmaterialet, der udgør den primære empiri i denne artikel, supplerer vi materialet med nogle eksempler, der stammer fra vores arbejde i psykiatrien. Vi arbejder til dagligt i Kompetencecenter for Dobbeltdiagnoser, der er en lille forsknings- og udviklingsafdeling, der arbejder med at forbedre indsatsen for mennesker med en dobbeltdiagnose. Som et led i dette arbejde taler vi ofte med personalemedlemmer i psykiatrien om, hvad de oplever af udfordringer i arbejdet 
med patienter med en dobbeltdiagnose. Vi underviser ofte i, hvad dobbeltdiagnose er, hvad det giver af udfordringer, hvordan behandlingen er organiseret, og hvad patienter med en dobbeltdiagnose har af ønsker til behandlingen. Denne interaktion med personale fra psykiatrien giver en række input, som supplerer det systematiske interviewmateriale, og som vi trækker ind som eksempler på nogle af vores pointer.

Som medarbejdere i et kompetencecenter i psykiatrien er vi en del af det system, som vi i denne artikel analyserer og diskuterer. Vi behandler dog ikke selv patienter. Man kan karakterisere vores position som kritisk i forhold til de praksisser og kulturelle logikker, der gør behandlingen af patienter med en dobbeltdiagnose vanskelig, men samtidig loyal forstået på den måde, at vi ønsker at bidrage til at gøre behandlingen bedre ved at hjælpe personalet i psykiatrien til i højere grad at kunne løfte deres opgave i forhold til patienter med en dobbeltdiagnose.

\section{Felt}

Den institution, som vi her beskæftiger os med, er den regionale behandlingspsykiatri. Det vil sige den del af sundhedsvæsenet, der behandler de mest alvorlige psykiske sygdomme såsom skizofreni, bipolar lidelse, svær depression, svære angstproblematikker, svære personlighedsforstyrrelser og svære spiseforstyrrelser, samt svære, akutte rusmiddelforgiftninger ${ }^{3}$.

Behandlingspsykiatrien består af det, man kalder den stationære psykiatri og den ambulante psykiatri. Den stationære psykiatri er de behandlingstilbud, der ligger på hospitalerne: de psykiatriske akutmodtagelser og lukkede og åbne sengeafsnit. I den ambulante psykiatri findes de distriktspsykiatriske centre, hvor patienterne møder til behandling og opsøgende tilbud, hvor psykiatriske medarbejdere opsøger patienter i deres eget hjem.

De behandlingsmæssige tiltag, som man benytter sig af i psykiatrien, er medicin, ECT (Electro Convulsive Therapy), psykoterapi, miljøterapi, psykoedukation, sociale foranstaltninger som forbereder patienten på at kunne klare sig i lokalmiljøet efter behandling og pårørendearbejde.

Frem til slutningen af 1960'erne foregik stofmisbrugsbehandling primært i psykiatrien (Kragh, 2015). Dette ændrede sig dog i slutningen af 1960'erne og starten af 1970'erne, hvor der sker en etablering af stofmisbrugsbehandling i nye sociale tilbud. Hvor alkoholbehandling forblev en del af det psykiatriske behandlingsfelt skete der en eksklusion af stofmisbrugerne (Ibid, se også Winsløw, 1984). De kon- 
krete processer og institutionelle rationaler i denne proces er dårligt belyst i forskningslitteraturen, så hvorfor det skete, ved vi ikke. Men vi kender resultatet, som er en psykiatri, der ofte ikke ser det som sin opgave at behandle stofmisbruget hos mennesker, der både har et misbrug og en psykisk sygdom.

Der er selvfølgelig tale om en analytisk forsimpling at tale om psykiatrien som en samlet enhed med én måde at håndtere misbrug på, sådan som vi gør i denne artikel. Psykiatrien er ikke en ting, men består af en masse forskellige tilbud, en række forskellige behandlingstilgange, mange forskellige personalemedlemmer og mange forskellig patienter. Og der er selvfølgelig også forskellige syn på stoffer og på de mennesker, der bruger dem. Når vi alligevel tillader os at gøre det her, er det dels fordi, at de psykiatriske institutioner også er præget af en fælles faglighed og en fælles praksis, der er genkendelig på tværs af institutionerne og de forskellige mennesker, der arbejder der. Og fordi psykiatrien er en konstruktion, der giver mening for de patienter, som vi har talt med.

\section{Misbrug mødes med fordømmelse}

Som nævnt indledningsvis er interviewene blevet lavet i forbindelse med en undersøgelse af sammenhængen mellem dobbeltdiagnose og bæltefiksering. Men i patienternes fortællinger om deres erfaringer med psykiatrien var det ikke bæltefikseringer (og andre former for tvang), der blev nævnt som den primære udfordring. Det største problem, patienterne oplever i psykiatrien, er, at de ikke bliver mødt og behandlet ordentligt og kvalificeret. Patienterne har alle en oplevelse af at blive mødt med fordømmelse på grund af deres misbrug. En patient fortalte: "Jeg kan bare mærke, at de ikke kan lide mig. Der er ingen, der kan lide narkomaner".

Patienterne fortæller om at henvende sig i akutmodtagelsen og blive afvist med beskeder, såsom: "stoffer er ikke acceptable i psykiatrien", eller "det her er ikke noget afvænningssted". Flere nævner, at de ofte fortier deres misbrug i kontakten med psykiatrien af frygt for ikke at blive indlagt, når de har brug for det.

Et andet stort problem, som patienternes fortællinger om mødet med behandlingspsykiatrien vidner om, er en oplevelse af at blive mødt med mistro og mistænksomhed. Det er en udbredt fornemmelse blandt patienterne, at meget personale er af den opfattelse, at patienterne lyver. En sagde: "Lægerne og personalet vil gerne have, at vi stoler på dem. Men de tror jo ikke på os", mens en anden sagde: "Personalet tror, vi laver zig-zag og fortæller historier". 
Når patienterne fortæller om deres erfaringer med det psykiatriske behandlingssystem, beskriver de ofte situationer, hvor de har en klar oplevelse af, at personalet ikke er rimelige og indfører restriktioner på baggrund af deres mistro og mistænksomhed i forhold til patienterne. En retspsykiatrisk patient, som vi kalder for Bilal, var en af dem, der fandt sig selv i sådan en situation. Bilal har været indlagt i otte måneder og fortæller:

"Første gang jeg fik besøg af min far, den dag kom der stoffer ind på afdelingen, og så siger personalet til overlægen, at når Bilals far kommer på afdelingen, så kommer der masser af stoffer, og det gik ud over mig. Jeg har ikke fået flere besøg af min familie. Jeg kan ikke få besøg af min far. Jeg kan ikke engang få lov at se min lille datter - på grund af falske oplysninger. Jeg har ikke set hende i otte måneder. Det er svært. Jeg kan næsten ikke holde det ud".

Frem for at få hjælp til det, de oplever at have brug for, herunder misbrug, beskriver patienterne altså et psykiatrisk behandlingssystem, der på mange måder dømmer dem ude.

Et bud på, hvorfor dette i praksis foregår, er, at det psykiatriske personale i situationer som ovenstående i højere grad trækker på en generel samfundsmæssig opfattelse af mennesker, der misbruger stoffer, end på en psykiatrisk-faglig opfattelse. En amerikansk undersøgelse peger på, at misbrug af illegale stoffer er en af de mest stigmatiserende praksisser i det moderne samfund. Forfatterne skriver:

"De samfundsmæssige normer i USA definerer stofbrug som en uacceptabel adfærd, og mange har negative holdninger til mennesker, der bruger illegale stoffer. Illegale stofbrugere bliver opfattet som svage, umoralske og som udgørende en risiko for samfundet [....] I USA bliver stofbrug set som illegalt og det bliver primært håndteret som et kriminalitetsproblem, snarere end som et helbredsproblem, der kan forebygges og behandles" (Ahern, Stuber \& Galea, 2007: 189, vores oversættelse).

Vi har ikke videnskabelige undersøgelser af, hvordan man i det danske samfund generelt ser på mennesker med et stofmisbrug, men vi vil vurdere, at noget tilsvarende gør sig gældende i en dansk kontekst. Og man kan i hvert fald se overlap mellem, sådan som patienterne beskriver at blive opfattet og de karakteristika, som den amerikanske undersøgelse fandt. Der er formentlig mange forklaringer på, hvorfor stofmisbrug har denne position i vores samfund. Kritisk sociologi pe- 
ger blandet andet på, at stofmisbrugerne udfordrer det kapitalistiske samfunds logik om arbejde og nydelse gennem forbrug ved at søge at undslippe arbejdet og søge nydelsen gennem illegale varer (dvs. stoffer) (Bjerg, 2008; se også Fraser, More \& Keane, 2014). Dertil kommer selvfølgelig, at der er tale om en ulovlig praksis, som samfundet generelt fordømmer og sanktionerer.

\section{Patienter med en dobbeltdiagnose bliver opfattet som andenrangs patienter}

Hvor stigmatiseringsproblematikken handler om generelle samfundsmæssige forhold, vil vi i dette afsnit kigge nærmere på nogle af de interne logikker i psykiatrien, der kan spille en rolle i mødet med dobbeltdiagnosepatienter.

Når de interviewede patienterne beskriver deres erfaringer med psykiatrien, tager de ofte hændelser op, hvor de har haft en følelse af at være en form for andenrangspatient, der ikke har ligeså meget ret til en sengeplads i psykiatrien som de patienter, der ikke har et misbrug. Nogle af patienterne beskriver dette som en ubestemmelig fornemmelse, de har, når de er indlagt. Andre fortæller om konkrete hændelser, hvor personalet har henvist mere direkte til, at de tager sengepladser fra patienter (uden misbrug), som i højre grad har brug for dem. En patient sagde: "Jeg var bare en fucking alkoholiker, der optog pladser fra de psykisk syge".

Patienterne fortæller også, at der som regel ikke bliver spurgt ind til deres misbrug, når de er indlagt. Deres misbrug bliver ikke set som et problem, som patienten legitimt kan forvente, at psykiatrien skal hjælpe dem med. I sammenhæng hermed udgør abstinenssymptomer et særligt problem, og en del af patienterne peger på, at personalet ikke hjælper dem nok med deres abstinenser. I et interview hvor spørgsmålet om at være abstinent efter opioider ${ }^{4}$ på et åbent afsnit kom op, betonede en patient, at dette var noget, han stod meget alene med: "De kan ikke gøre det helt store". Interviewer: "Hvad plejer du så at gøre?" Patient: "Så er jeg gået ud og taget noget". I et andet interview hvor spørgsmålet omkring abstinenser efter opioider kom op i forhold til lukkede afsnit, beskrev en patient sin afmagt over langt fra at få tilstrækkelig abstinensbehandling:

"Man er helt magtesløs, hvis man vil ud for at tage stoffer. Hvis man vil snakke med lægen, siger de, at de vil ringe til lægen, men de gør det ikke. Du kan ikke gøre noget. Du kan ikke komme ud, og de giver ikke noget." 
Eksemplerne her viser tydeligt, at misbrugsproblematikker - herunder håndtering af abstinenssymptomer - ikke er noget, som personalet opfatter som et område, de behøver at beskæftige sig med. Og det betyder også, at patienter med disse problemer ikke bliver set som patienter, som man behøver at beskæftige sig med. Når man ser på citaterne både ovenfor i dette afsnit og ikke mindst $\mathrm{i}$ afsnittet om stigmatisering, bliver det tydeligt, at denne afvisning også har et element af, at disse patienter ikke fortjener, at man beskæftiger sig med dem - at de ikke er rigtige patienter.

En måde at forstå, hvad en rigtig patient er for en størrelse, kan man få ved at kigge på det klassiske begreb 'patientrolle', som det blev beskrevet af den amerikanske sociolog Talcott Parson (1951). Ifølge Parson består patientrollen af nogle forventninger og, hvis man lever op til disse, nogle rettigheder. Forventningerne er, at patienten skal prøve at blive rask, og at patienten skal søge kompetent hjælp og samarbejde med det sundhedsfaglige personale. Rettighederne er, at patienten ikke behøver at leve op til sin almindelige rolle, og at patienten ikke er ansvarlig. Selv om Parsons tilgang efterfølgende er blevet udsat for omfattende kritik (se f.eks. Gannick, 2005), så vil vi vurdere, at beskrivelsen fortsat identificerer nogle grundlæggende karakteristika i forhold til, hvad det vil sige at være patient.

Patienter med en dobbeltdiagnose udfordrer de forventninger, som der traditionelt stilles til en patient. Når patienter med en psykisk sygdom også misbruger stoffer, så betyder det, at patienterne bliver mere syge og bliver sværere at behandle - dobbeltdiagnosepatienterne gør altså det modsatte af, hvad en rigtig patient bør gøre. Og selvom de nok ønsker hjælp fra det psykiatriske behandlingssystem, så bliver det af det psykiatriske personale ofte opfattet som om, de ikke samarbejder.

Et led, i at patienter skal ønske at blive raske og skal samarbejde med det sundhedsfaglige personale, handler om, at man skal følge personalets behandlingsanbefalinger. Her forudsættes det, at det er personalet, der ved, hvad der er bedst for den enkelte patient at gøre i konkrete situationer, og at patienten - for at kunne få adgang til patientrollen - accepterer det sundhedsfaglige personales autoritet i forhold til at bestemme behandling. Dette gælder ikke mindst den medicinske behandling, som jo er et af de centrale lægefaglige områder. Patienter, der udover deres psykiske sygdom også har et misbrug af stoffer, er inde og pille ved dette monopol. De psykoaktive komponenter i stofferne, som patienterne tager, påvirker de samme signalstoffer, neurotransmittere mm. som den psykofarmaka, som psykiatere udskriver og psykiatriske sygeplejersker distribuerer. Patienter med et 
stofmisbrug bevæger sig dermed ind på et område, som personalet er vant til at opfatte som deres eksklusive virkefelt. Og samtidig vælger patienterne også en anden effekt - for eksempelkokainens opkvikkende effekt - fremfor den effekt, som sundhedspersonalet ønsker at give dem - eksempelvis den antipsykotiske og beroligende effekt ved den antipsykotiske medicin. De tiltager sig altså ikke alene råderet over et domæne, som de - set i lyset af Parsons begreb om patientrollen - ikke har ret til - de forkaster også den effekt, som personalet vurderer, er den rigtige for dem.

Inden for dobbeltdiagnoseområdet har man igennem mange år talt om 'selvmedicinering' som en del af forklaringen på, hvorfor mennesker med en psykisk sygdom brugte rusmidler ${ }^{5}$ (Gregg, Barrowclough \& Haddock, 2007). Selvmedicinering kan ud fra en medicinsk logik give mening, så længe patienterne ikke har adgang til den rigtige medicinering (som altså er den, lægen bestemmer). Men når først patienterne er en del af det psykiatriske behandlingssystem - og er blevet diagnosticeret og sat i rigtig behandling - er der også en helt klar forventning om, at de så også holder op med selvmedicineringen. Og det er her, at dobbeltdiagnosepatienternes praksis med fortsat at indtage psykoaktive substanser, som de selv anskaffer, selv administrerer og selv indtager, kommer til at udfordre patientrollen.

Når patienter med en dobbeltdiagnose ikke lever op til patientrollen, betyder det, at personalet bliver udfordret i deres arbejde og ikke på samme måde som med andre patienter bliver bekræftet $i$, at de gør det rigtige. Dette forhold genfinder vi empirisk blandt noget af det personale, som vi arbejder sammen med i psykiatrien. I en rundspørge blandt personalemedlemmer, der var blevet udpeget til nøglepersoner på dobbeltdiagnoseområdet, svarede flere, at de oplevede det som et svært felt at arbejde i, fordi problemstillingerne var sværere at behandle. Denne problematik vil vi kigge nærmere på i vores tredje analytiske afsnit.

\section{Patienterne oplever ikke at få hjælp til deres problemer - herunder misbrug}

Patientudsagnene ovenfor illustrerer tydeligt patienternes oplevelse med at blive afvist i psykiatrien på grund af deres misbrug. Størstedelen af patienterne har også erfaringer med at "ryge ind og $u d$ ", som de selv kalder det. Hermed henviser patienterne til, at de ofte henvender sig i akutmodtagelsen, eller de bliver indlagt 
og så udskrevet efter en eller få dage - uden at have fået hjælp til deres problemer. Her er nogle af de talrige måder, patienterne selv formulerer sig om dette på.

En siger: "Det virker som om, at her skal man bare lige placeres, og når der så er gået et par dage, så er man frisk nok til at komme ud og tumle rundt med alle problemerne igen, og det er man jo slet ikke."

En anden fortæller: "Når jeg kommer, så er jeg jo for det meste, jaaa [svært beruset], så kan de jo forst snakke med mig dagen efter, og så er jeg rigtig mange gange blevet udskrevet. Når jeg først vågner op efter en druktur, så får jeg lyst til at drikke endnu mere, fordi så har jeg det ad helvede til. Og når de så siger, at de vil udskrive mig, så tænker jeg bare 'halleluja'. Så er jeg ikke den, der bliver hængende, og jeg bliver heller ikke opfordret, så der er ikke den støtte, der måske skulle være."

En tredje siger: "De [personalet] sidder inde på kontoret, og så sørger de for, at man fär noget at spise, og så sætter de sig derind igen, og så kommer der en læge og snakker, og så bliver man hojst sandsynlig udskrevet, og så har man bare de samme problemer, som inden man kom. Jeg troede, at de der psykiatriske skadestuer var der for at sætte et eller andet $i$ gang, så man ikke bare blev, 'nå, men du tager bare hjem'".

Når patienterne er indlagt, oplever de som regel ikke, at personalet beskæftiger sig med deres misbrug. Patienterne har generelt en oplevelse af, at personalet ikke har forståelse for, hvor stor en rolle misbruget spiller i deres liv. En patient sagde sådan her: "Man må ikke misbruge, og så føler man sig låst, hvis det er det, man plejer at gøre for at få hverdagen til at køre. De forstår ikke, hvor vigtigt det er."

Det er karakteristisk i patienternes fortællinger, at de oplever et psykiatrisk personale, der ikke tager sig af deres misbrug. Slår man op i den psykiatriske diagnosemanual - ICD-10 (WHO, 1994) - har misbrug6 af rusmidler sit eget kapitel og sine egne diagnosekoder7. Så formelt set er misbrug en del af det psykiatriske felt. Men i praksis er det dog langt fra altid tilfældet, at et misbrug resulterer i en misbrugsdiagnose. En dansk undersøgelse tilbage fra år 2000 fandt, at ca. 25 \% af de indlagte patienter havde en misbrugsdiagnose, men at $50 \%$ af patienterne opfyldte kriterierne for en misbrugsdiagnose (Hansen et al., 2000).

Det er dog ikke kun i forhold til diagnosticering af misbrug, at psykiatrien har et 'blindt punkt'. Det gælder også i forhold til mere generelt at spørge ind til et 
eventuelt misbrug og dets konsekvenser og i forhold til at tilbyde behandling af misbrugsproblematikkerne. Den følgende observation, foretaget af en af forfatterne, illustrerer dette:

På en kursusdag om dobbeltdiagnose fortæller en kontaktperson på et botilbud for unge med psykiske vanskeligheder om følgende erfaringer: "Jeg forstår det ikke", siger hun. "Når man sidder til sådan en samtale i psykiatrien, og den unge sidder med helt røde øjne og er tydeligt påvirket af den joint, som hun har roget, lige inden vi kom. Hvordan de kan lade være med at spørge til det? Hvordan de kan lade være at synes, at det er vigtigt? Tit er det mig, der må sidde og sige - øh, I skal lige være opmærksomme på, at XXX også har et misbrug af hash".

En måde at forklare, hvorfor misbrug ikke bliver adresseret i psykiatrien, er at undersøge denne praksis ud fra det perspektiv, som Jöhncke, Svendsen og Whyte kalder sociale teknologier (2004). Sociale teknologier er ifølge Jöhncke et al. de behandlingstiltag, som man i en given behandlingsmæssig sammenhæng har til rådighed. Deres centrale analytiske greb er at påpege, at disse teknologier definerer de problemer, man ser det som sin kerneopgave at løse. Det vil sige, i stedet for at det er problemerne, der bestemmer hvilke løsninger, der skal i spil, er processen reelt omvendt: De løsninger, der er til rådighed, bestemmer, hvilke problemer vi ser. De peger videre på, at der i denne proces også sker en definition af målgruppen, nemlig dem der har den slags problemer, som man kan afhjælpe med de indsatser, man har til rådighed, og en eksklusion af dem som man ikke kan hjælpe (Ibid.).

Det dominerende behandlingstiltag i den del af psykiatrien, hvor patienter med en dobbeltdiagnose oftest vil være at finde, er forskellige former for medicin (Johansen, 2006; Luhrmann, 2000). Disse kan eventuelt suppleres af samtaler baseret på kognitiv adfærdsterapi eller forskellige former for miljøterapi. Disse betragtes som velegnede til at behandle specifikke psykiatriske tilstande - som for eksempel skizofreni og depression - men er mindre velegnede til håndtering af komplekse problemstillinger, hvor der er tale om flere diagnoser og ikke de 'rene' lidelser.

Selvom psykiatrien, som tidligere nævnt, ikke kan skæres over en kam, så er den baseret på nogle grundlæggende antagelser, som kan findes i diagnosesystemets opbygning, og som afspejles i psykiatriens grundbøger og i forskningsartikler. Både den amerikanske DSM-5 og WHO's ICD-10 bygger på en kategorisk opfattelse af psykiske lidelser. Dette betyder, at der er en antagelse om, at der er 
klare, kvalitative skel mellem diagnoser, at man enten har eller ikke har en given diagnose, og at en diagnose afspejler en underliggende forstyrrelse af hjernens funktion (Compton \& Guze, 1995). Steven E. Hyman, som er psykiater og involveret i udformningen af DMS-5 og ICD-11, giver udtryk for bekymring i forhold til om den strengt kategoriske model er den mest hensigtsmæssige: "Spørgsmålet er, om mennesker med relateret komorbiditet bedst forstås som havende to eller flere adskilte [...] lidelser eller som havende en enkelt lidelse, hoor komplekse ætiologiske faktorer bidrager til udvikling af varierede symptom-billeder, der kan ændre sig over tid, og som påvirkes af miljømæssige variabler?" (2010, vores oversættelse).

Problemet forværres, mener Hyman, af, at behandlingsmetoder valideres på grupper, som har en 'ren' diagnose - det vil sige, som passer ind i en og kun en diagnostisk gruppering (Hyman, 2010). Dette placerer de mennesker, som ikke passer ind i enkelte diagnostiske kategorier i en slags evidensmæssigt ingenmandsland, fordi de behandlingsmetoder, der er udviklet, er afprøvet på en gruppe, som i væsentlige henseender ikke svarer til dem, der ikke passer ind i det, som Hyman kalder 'diagnostiske siloer' (ibid.).

Ud fra den ideelle psykiatriske behandlingsmodel stilles der en diagnose og efterfølgende anvendes en behandling, som der er evidens for er effektiv i forhold til den beskrevne lidelse, eksempelvis. antipsykotisk medicin ved psykose, antidepressiv medicin ved depression, kognitiv terapi for angst, depression, skizofreni og så videre. Når personalet i psykiatrien ikke ser misbrug som et problem, som de skal afdække og behandle, handler det - ud fra de sociale teknologiers perspektiv - om, at de ikke har teknologier/behandlingstiltag, som gør det relevant for dem at identificere misbruget (se også Johansen, 2007), som når der for eksempel. ikke findes kognitiv terapi for dobbeltdiagnose eller anti-dobbeltdiagnose medicin. Tværtimod, kan man sige, er det mere handlingsanvisende ikke at se misbruget $\mathrm{i}$ sådan en situation.

Denne psykiatriske behandlingsmodel bevæger sig selvfølgelig også ud over de mere tekniske og oplevelses-fjerne perspektiver, vi har beskrevet ovenfor, da den også har indflydelse på, hvordan mennesker med en dobbeltdiagnose bliver mødt, når de får kontakt med behandlingssystemet. Desuagtet at psykiatrien er et sammensat system, som kan udmøntes meget forskelligt i konkrete behandlingssituationer, ligger der dels via paletten af tilgængelige sociale teknologier, og dels i diagnose- og evidenssystemets eksklusion af sammensatte problemstillinger, en potentiel spaltning af patienten i noget, vi gerne vil forholde os til, og noget som er mindre velkomment. 
Potentielt set rækker afvisningen dog længere end til bare misbruget og mødet med den psykiatriske afdeling - det kan også have implikationer for, hvordan de berørte patienter mere grundlæggende oplever sig selv og deres plads i samfundet. Inspireret af Axel Honneth, der arbejder inden for kritisk filosofi, og hans arbejde med anerkendelse, kan man pege på, at når problematikkerne ved et aktivt misbrug ikke betragtes eller italesættes som en del af patienten og dennes liv, udsættes patienten for moralske krænkelser, hvilket medfører, at patientens selvagtelse ikke kan opretholdes (Honneth, 2003). Ifølge Honneth er der et iboende universelt behov for anerkendelse hos mennesket, og når denne anerkendelse ikke finder sted, kan det opleves, som at dets moral og ret bliver krænket $\mathrm{i}$ konkrete situationer (ibid.). I tilfældet med dobbeltdiagnose er der en risiko for, at psykiatriens behandlingsmodel medfører netop denne form for invalidering, som det også kan ses illustreret i de interviews, der indledte dette afsnit.

\section{Dobbeltdiagnosepatienters ønsker til psykiatrien}

Det kan ikke overraske, at patienterne har nogle ønsker til psykiatrien, der er helt anderledes end den situation, de oplever i dag. Patienternes ønsker går helt overordnet på at blive mødt og behandlet ordentligt og kvalificeret. Patienterne ønsker sig personalemedlemmer, som er lyttende og imødekommende - fremfor fordømmende - $\mathrm{i}$ forhold til deres misbrug og personalemedlemmer, der ser misbrug som en integreret del af de problemer, som patienterne har brug for hjælp til at få løst.

Derudover har patienterne en række ønsker til personalets tilgang til og samspil med dem, som ikke snævert handler om deres misbrug. Det første er personalemedlemmer, der interesserer sig for patienterne. Patienterne føler sig ofte ignoreret og overladt til sig selv, når de er indlagt, og de efterlyser personale, der gider være sammen med dem. Det andet ønske er personale, der har lyst til at arbejde med dem. Det vil med andre ord sige personale, der ikke alene anser deres arbejde som et arbejde, men er varme og kærlige og gerne giver lidt ekstra af sig selv. Og så ønsker patienterne sig personale, som 'ser mennesket bag patienten'. Patienterne har ofte en følelse af, at personalet glemmer, at patienten (også) er et menneske, og nogle gange oplever patienterne, at de slet ikke bliver anset og behandlet som et menneske. Patienterne efterlyser 'professionelle mennesker', der tilbyder en menneskelig og faglig indsats, der kan hjælpe patienterne med de komplekse problemstillinger, herunder misbrug, som de henvender sig med. 


\section{Konklusion}

I denne artikel har vi præsenteret en række dobbeltdiagnosepatienters fortællinger om, hvordan de bliver mødt i psykiatrien i dag. De beretter om afvisning, om stigmatisering, om ikke at høre til, og om ikke at blive behandlet for deres problemer. Vi har stillet spørgsmålet: Hvordan kan det være, at patienter med en dobbeltdiagnose bliver behandlet som 'psykiatriens stedbørn'? Og på baggrund af en indholdsanalyse af patienternes fortællinger har vi fundet tre forskellige svar, der dog på mange måder understøtter hinanden. For det første, at stofmisbrug generelt i samfundet bliver omfattet af stigmatisering, og at det også gælder personalet på de psykiatriske afdelinger. For det andet, at patienterne ikke lever op til rollen som rigtige patienter - blandt andet er det fordi, de fortsætter med at misbruge, når de kommer i psykiatrisk behandling. Og for det tredje fordi at psykiatrien arbejder med en forståelse af psykisk sygdom, der vanskeliggør behandlingen af komplekse lidelser som dobbeltdiagnose.

Artiklen peger således på, at selv om der igennem de senere år har været en række projekter, der har sigtet mod at styrke indsatsen for patienter med en dobbeltdiagnose, så står psykiatrien fortsat overfor massive udfordringer, når det gælder om at sikre denne patientgruppe en god behandling.

\section{Noter}

1: Vi bruger ordet 'misbrug' til at beskrive en praksis, hvor folk på en eller anden måde har et problematisk forhold til deres indtag af rusmidler.

2: Vi fokuserer i denne artikel på brugen af stoffer. En del af de problematikker, som vi beskriver, vil dog også være gældende for alkohol.

3: Den regionale behandlingspsykiatri har behandlingsansvaret for de alvorligste psykiske sygdomme. De mindre alvorlige sygdomme skal behandles i den primære sektor - det vil sige enten hos praktiserende læge, privatpraktiserende psykiater eller privatpraktiserende psykolog.

4: Opioider er en gruppe af stoffer, som oprindeligt blev udvundet af opiumsvalmuen, og som virker smertestillende på vores centralnervesystem. De mest kendte er morfin og heroin. I dag fremstilles også kunstige opioider - her er metadon nok det mest kendte.

5: Selvmedicineringshypotesen er dårligt underbygget rent forskningsmæssigt. Der refereres dog ikke desto mindre ofte til den i praksis som forklaring på det udbredte misbrug blandt mennesker med psykisk lidelse.

6: Som nævnt i note 1 så bruger vi betegnelsen misbrug som en samlet betegnelse for et problematisk brug af rusmidler. I ICD-10 finder man dog ikke misbrug som en diag- 
nose. Der kan man diagnosticere 'skadeligt brug' og 'afhængighed'. Når vi taler om misbrug, så rummer det begge diagnoser.

7: Dobbeltdiagnose har ikke sin egen selvstændige diagnose eller diagnosekode - vil man kode dobbeltdiagnose, så koder man den psykiske sygdom som hoveddiagnose og misbruget som bidiagnose (eller omvendt).

\section{Referencer}

Ahern, J., Stuber, J. \& Galea, S. (2007). Stigma, discrimination and the health of illicit drug users. Drug and alcohol dependence, 188-196. doi: 10.1016/j.drugalcdep.2006.10.014

Bjerg, O. (2008). For tæt på kapitalismen: ludomani, narkomani, købemani. København: Museum Tusculanums Forlag.

Busch, S., Rasmussen, A., Mårtensson, S. \& Johansen, K.S. (2017). Dobbeltdiagnose og Bæltefiksering. En undersøgelse af sammenhængen mellem dobbeltdiagnose - den samtidige forekomst af psykisk sygdom og misbrug - og bæltefiksering. Roskilde: Kompetencecenter for Dobbeltdiagnoser, Region Hovedstadens Psykiatri.

Compton, W.M. \& Guze, S.B. (1995). The neo-Kraepelinian revolution in psychiatric diagnosis. European archives of psychiatry and clinical neuroscience, 245, 196-201. https://doi. org/10.1007/BF02191797.

Fraser, S., More, D. \& Keane, H. (2014). Habits. Remaking Addiction. Hampshire: Palgrave MacMillan. doi: 10.1057/9781137316776

Gannick, D.E. (2005). Social sygdomsteori - et situationelt perspektiv. Frederiksberg: Forlaget Samfundslitteratur.

Gregg, L., Barrowclough, C. \& Haddock, G. (2007). Reason for Increased Substance Use in Psychosis. Clinical Psychological Review, 27, 494-510. https://doi.org/10.1016/j. cpr.2006.09.004.

Hansen, S.S., Munk-Jørgensen, P., Guldbæk, B., Solgård, T., Lauszus, K.S., Albrechtsen, N., Borg, L., Egander, A., Faurholdt, K., Gilberg, A., Gosden, N.P., Lorenzen, J., Richelsen, B., Weischer, K. \& Bertelsen, A. (2000). Psychoactive substance use diagnoses among psychiatric in-patients. Acta Psychiatrica Scandinavica, 102, 432-438. doi: 10.1034/j.16000447.2000.102006432.x

Honneth, A. (2003). Behovet for anderkendelse. København: Hans Reitzels Forlag. doi: -

Hyman, S.E. (2010). The diagnosis of mental disorders: the problem of reification. Annual review of clinical psychology, 6, 155-179.

Johansen, K.S. (2006). Kultur og psykiatri - en antropologi om transkulturel psykiatri på danske hospitaler. Department of Anthropology. Copenhagen: University of Copenhagen.

Johansen, K.S. (2007). Kategorisering i psykiatrien: Patienter med anden etnisk baggrund end dansk. In K.F. Olwig, \& K. Pærregaard (Eds.), Integration: Antropologiske perspektiver. København: Museum Tusculanumes Forlag. doi: -

Johansen, K.S. (2009). Dobbelt diagnose - Dobbelt behandling. Glostrup: KABS VIDEN.

Jöhncke, S., Svendsen, M.N. \& Whyte, S.R. (2004). Løsningsmodeller: Sociale teknologier som antropologisk arbejdsfelt. In K. Hastrup (Ed.), Viden om verden: En grundbog i antropologisk analyse. København: Hans Reitzels.

Kragh, J.V. (2015). Fra morfinisme til dobbeltdiagnoser. Bibliotek for læger, 207, 312-332. 
Landheim, A., Wiig, F.L., Brendbekken, M., Brodahl, M. \& Biong, S. (2016). Et bedre liv. Historier, erfaringer og forskning om recovery ved rusmiddelmisbruk og psykiske helseproblemer. Oslo: Gyldendal Akademisk.

Ludvigsen, K.B. \& Brünés, N. (2013). Socialsygepleje i somatik og psykiatri. En antopolgi over erfaringerne fra Projekt Socialsygepleje - det gode patientforløb. Glostrup.

Luhrmann, T.M. (2000). Of Two Minds. The Growing Disorder in American Psychiatry. New York: Alfred A. Knopf.

Merinder, L.B. (2007). Psykiatriens Stedbørn. STOF. Tidsskrift for Stofmisbrugsområdet, 28-29.

Parsons, T. (1951). The Social System. London: Routledge \& Kegan Paul.

Pinderup, P. (Forthcomming). Improving the Knowledge, Attitudes, and Practices of Mental Health Professionals Regarding Dual Diagnosis Treatment - A Mixed Methods Study of an Intervention. Issues in mental health nursing.

Schmidt, L.M., Hesse, M. \& Lykke, J. (2011). The Impact of Substance Use Disorders on the Course of Schizophrenia - a 15-years Follow-up Study: Dual Diagnosis over 15 Years. Schizophr Res, 228-233. doi: 10.1016/j.schres.2011.04.011

Schulte, S.J., Meier, P.S. \& Stirling, J. (2011). Dual diagnosis clients' treatment satisfaction - a systematic review. BMC Psychiatry, 11, 1-12. doi: 10.1186/1471-244x-11-64

Toftdahl, N.G., Nordentoft, M. \& Hjorthoj, C. (2016). Prevalence of substance use disorders in psychiatric patients: a nationwide Danish population-based study. Soc Psychiatry Psychiatr Epidemiol, 51, 129-140. doi: 10.1007/s00127-015-1104-4

WHO (1994). ICD-10 Psykiske lidelser og adfærdsmæssige forstyrrelser. Klassifikation og diagnostiske kriterier. København: Munksgaard Danmark.

Winsløw, J.H. (1984). Narreskibet - en rejse i stofmisbrugerens selskab fra centrum til periferi af det danske samfund. Holte: SocPol. 